\title{
ECOPHYSIOLOGY OF CAATINGA NATIVE SPECIES UNDER SEMI-ARID CONDITIONS
}

\author{
ECOFISIOLOGIA DE ESPÉCIES NATIVAS DA CAATINGA EM CONDIÇÕES SEMI- \\ ÁRIDAS
}

\begin{abstract}
Alessandro Carlos MESQUITA ${ }^{1}$; Barbara França DANTAS ${ }^{2}$; Paulo Araquém Ramos CAIRO ${ }^{3}$
1. Professor Titular, Departamento de Tecnologia e Ciências Sociais - Universidade do Estado da Bahia - UNEB, Juazeiro, BA, Brasil. alessandro.mesq@yahoo.com.br; 2. Pesquisadora, Empresa Brasileira de Pesquisa Agropecuária (Embrapa Semiárido), Petrolina, PE, Brasil; 3. Professor Pleno, Departamento de Fitotecnia e Zootecnia, Universidade Estadual do Sudoeste da Bahia (UESB), Vitória da Conquista, BA, Brasil.
\end{abstract}

\begin{abstract}
Caatinga is a biome from the Brazilian northeastern semiarid region which needs further studies for the preservation of its native species. The aim of this study was to evaluate the physiological behavior of six native species. The experiment was arranged in six treatments (native species) and three replicates in a randomized block design. Net photosynthesis, transpiration, stomatal conductance, photosynthetic photon flux density, chlorophyll content, and soil moisture were evaluated. According to the results, Mimosa spp. had the lowest levels of chlorophyll content. In all species, water deficit caused significant decrease in transpiration rate and stomatal conductance. M urundeuva and Cnidoscolus spp. can be considered the most sensitive species to drought as changes in those variables also led to the decline in net photosynthesis. The other species can be considered more tolerant to drought, since net photosynthesis did not suffer significant decrease despite the harmful effects of water deficit on transpiration and stomatal conductance.
\end{abstract}

KEYWORDS: Photosynthesis. Plant-water relationship. Drought. Brazilian semiarid.

\section{INTRODUCTION}

Caatinga is an ecosystem found exclusively in northeastern Brazil and extends over 844,453 $\mathrm{km}^{2}$, which represents $9.92 \%$ of Brazilian territory (IBGE, 2010). It is a seasonal dry tropical forest and is the most endangered ecosystem of the Northeastern semiarid region of Brazil (SANTOS et al.2014). Thus, plant species with economic potential could have two features: they improve the life quality of the local people and are important for biological conservation. In addition to anthropic threats, Caatinga must adapt to changes in climate (SANTOS et al. 2014).

Although it has one of the largest dry forest biodiversity, the Caatinga vegetation has been poorly studied and little protected. The forecast for semi-arid regions worldwide is an increase in the frequency of drought events, which may represent a threat to several species (DONOHUE et al.2013). Due to persistent environmental stress, Caatinga trees have developed their own survival strategies in order to ensure adequate water supply and mitigate the harmful effects of drought.

Drought is an abiotic factor which leads to decrease in photosynthetic rates, limiting crop growth and productivity throughout the world (JOHARI-PIREIVATLOU et al., 2010). These harmful effects on photosynthesis may be enhanced by high temperatures (YU et al., 2009). Decreased rates, both in photosynthesis and transpiration, have been widely observed in plants submitted to water deficits (HESSINI et al., 2009) in places with high atmospheric evaporative demand (FENG; CAO, 2005).

Photosynthesis is affected by drought, among other reasons, due to stomatal closure, which is an important strategy to maintain plant water status (GUO et al., 2010). Furthermore, photosystem II may also be damaged by environmental stress (ZHENG et al., 2009; SILVA et al., 2010).

Numerous studies have been carried out in order to obtain better understanding about drought tolerance strategies of Caatinga trees (Oliveira et al., 2016; Suresh et al., 2012). Studies on drought tolerance strategies of adult trees may also be required because they can better explain the physiological resources many species have used to survive and settle in such an extreme environment as Caatinga.

Thus, the aim of this study was to evaluate physiological behavior and drought tolerance strategies of six native tree species from a natural reserve area in Caatinga based on characteristics associated to gas exchange, chlorophyll content, and soil moisture. 


\section{MATERIAL AND METHODS}

The experiment was conducted at the Experimental Station of Embrapa Semi-Arid, which is a natural reserve area in Petrolina, Pernambuco State, Brazil (9 04' 25.3" S 40 19' 12.9" W), from August 2010 to March 2011. Six native species to the Caatinga were chosen for this study, namely: male and female plants of aroeira-do-sertão (Myracrodruon urundeuva M. Allem.); male and female plants of baraúna (Schinopsis brasiliensis Engl.); jurema-vermelha (Mimosa arenosa (Willd.) Poir.); jurema-preta (Mimosa tenuiflora (Willd.) Poir.); favela-de-galinha (Cnidoscolus bahianus (ULE) Pax \& Hoffm.); and favela-comum (Cnidoscolus vitfolius (Mill.) Pohl.) The accurate age of the plants was unknown as they are native species (not planted). Nevertheless, all of them were higher than $2 \mathrm{~m}$ and accepted as adult plants, with similar vegetative development stages.

Temperature (maximum, minimum, and mean), relative humidity (maximum, minimum, and mean), solar radiation, wind speed and direction, precipitation, evapotranspiration, and vapor pressure deficit were recorded and monitored at the Caatinga Meteorological Station of Embrapa Semi-Arid. Soil moisture contents at depths 0.0 to $2.5,2.5$ to 5.0, 5.0 to 10.0 , and 10.0 to $20.0 \mathrm{~cm}$ were determined using the gravimetric method.

Experimental design was in six treatments (species) with three replicates in randomized blocks. Relative chlorophyll index (CRI) was measured on different leaves of each plant, with three replicates, using a chlorophyll meter (Falker model CFL 1030). Net photosynthesis $(A)$, transpiration $(E)$, stomatal conductance $(g s)$, and photosynthetic photon flux density (PPFD) were measured in mature leaves using an infrared gas analyzer (IRGA, model LICOR LI-6400), from 9 to 11 a.m., on typical days of each season, i.e., during dry (August-October) and rainy (November-March) months.

Data were statistically examined using an analysis of variance (ANOVA) based on Tukey's test $(\mathrm{p} \leq 0.05)$, using Sisvar program.

\section{RESULTS AND DISCUSSION}

Climate data showed that the lowest temperatures (minimum and maximum) occurred in August. Thereafter, temperatures had a little increase in October $(27.8 ; 22.2$; and 34.9 ; mean, minimum, and maximum temperatures, respectively) and remained relatively unchanged until March (Figure 1A). During this period, mean temperature was $26.8^{\circ} \mathrm{C}$.

The highest precipitation (Figure 1B) was in December, but rainfall remained in the following months until March, although less intense. Global solar irradiance (Figure 1C) increased from November to January and monthly relative humidity (Figure 1D) rose from December to March. Hence, monthly mean evaporation (Figure 1F), insolation (Figure 1E), and wind speed (Figure 1G) decreased.

Annual precipitation in Caatinga varies from 250 to $900 \mathrm{~mm}$ and is uneven, with a long dry season (seven to nine months) and a short rainy season (three to five months) (IBGE, 2010). Furthermore, high temperatures lead to high evaporation and evapotranspiration.

The climate profile of Caatinga can be limiting for many species, since water availability is considered the most decisive abiotic factor for plant life (GIULIETTI et al., 2006, ARAÚJO et al., 2007, TROVÃO et al., 2007). Caatinga species, however, must have their own strategies to tolerate water deficit.

There was no precipitation in August and September, just a little rainfall in October and no precipitation again in November. Due to the fact that there was no significant precipitation during those four first months, soil moisture in November was the lowest in the experiment period (Figure 2) and it may have caused water stress.

During the experiment period, there were no significant differences in chlorophyll content among Cnidoscolus spp, M. urundeuva, and S. brasiliensis (Figures 3B, 3C and 3D). Mimosa spp. had the lowest chlorophyll content in the same period approximately $50 \%$ lower than the other species (Figure 3A). Chlorophyll content of Mimosa spp. was similar to that reported by Galvincio et al. (2010), who also have performed studies on photosynthetic pigments on this specie.

There is no physiological behavior pattern in Caatinga plants regarding chlorophyll content. It can vary among species, between months of a year and between years, both for shrub species and for trees, indicating that seasonality has an important influence on chlorophyll synthesis and, hence, on photosynthetic yield (Moura et al., 2008). 
A.

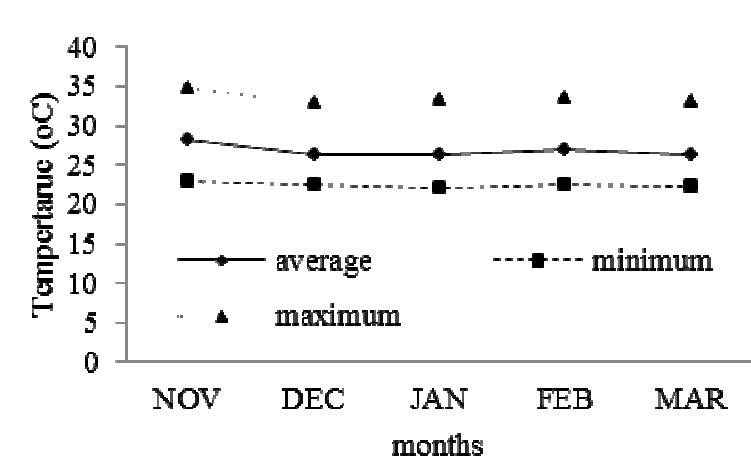

c.

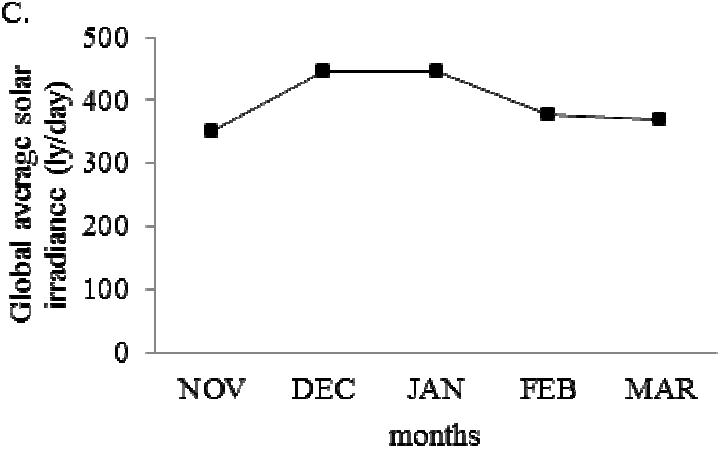

E.

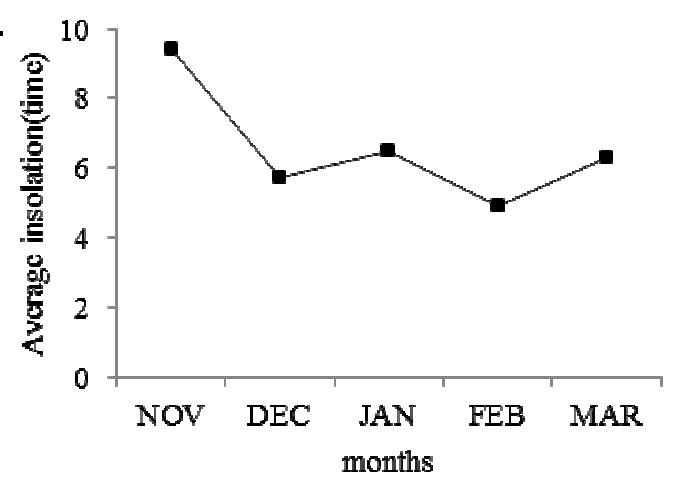

c.

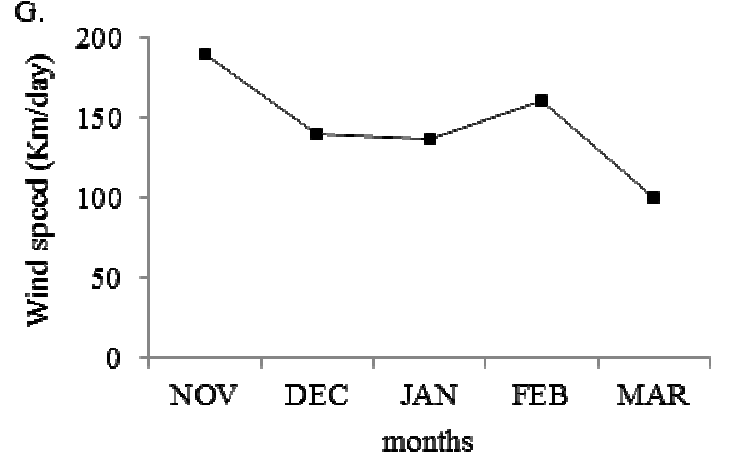

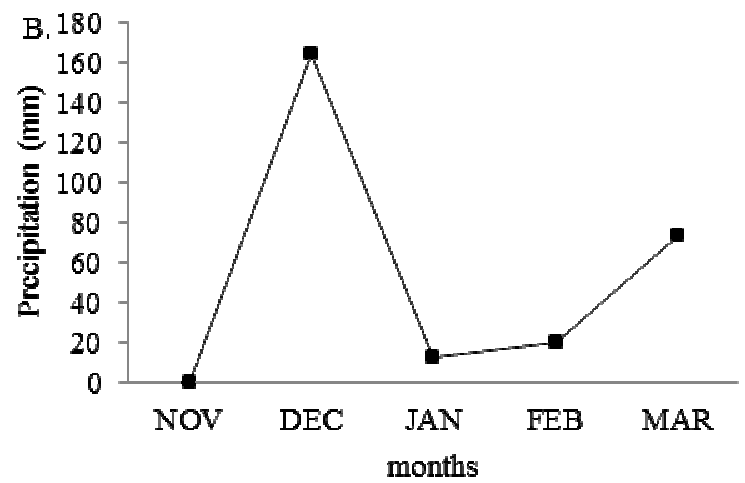
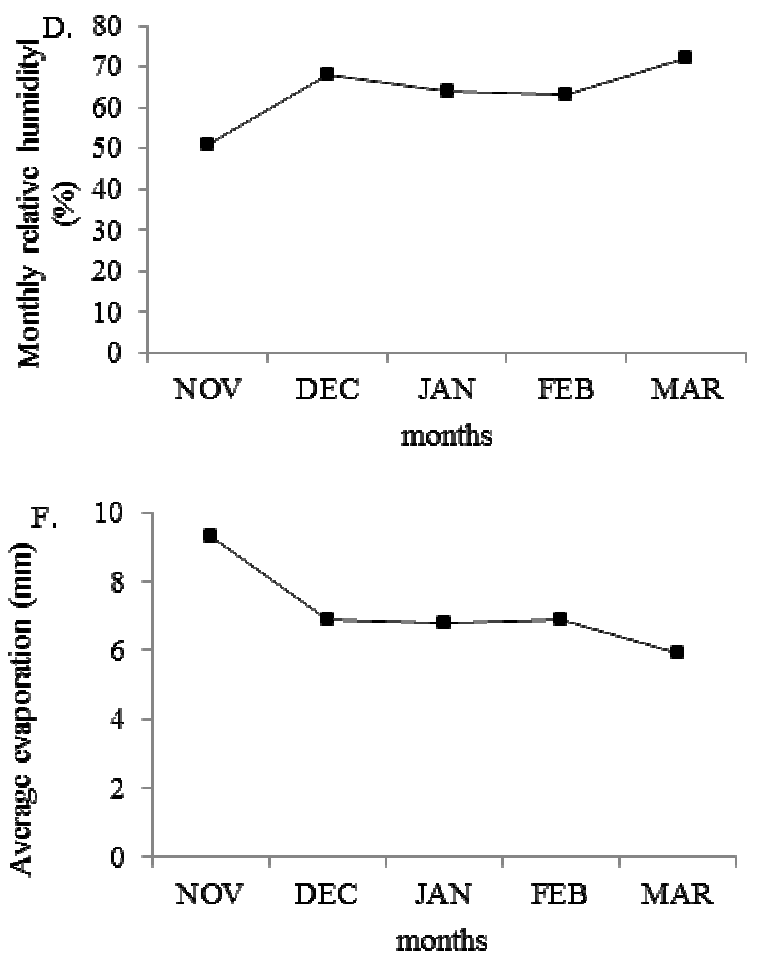

Figure 1. Monthly mean data of temperature (A), precipitation (B), global solar irradiance (C), relative humidity (D), insolation (E), evaporation $(F)$, and wind speed $(\mathrm{G})$ during the experiment period. Climate data are from the Meteorological Station, which is located at EMBRAPA Semi-Arid, Petrolina, Pernambuco state, Brazil. 


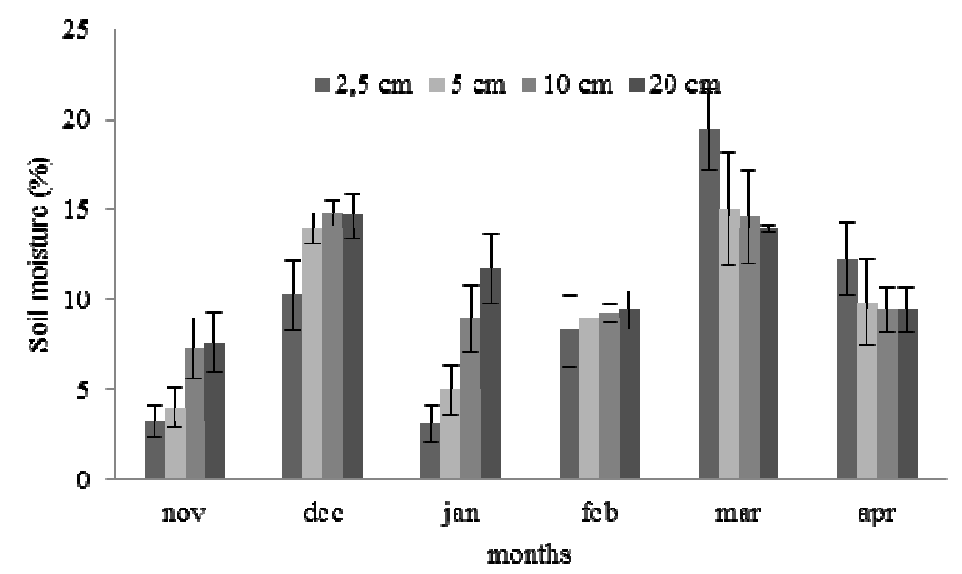

Figure 2. Soil moisture at different depths from November to April. The bars in each column indicate the standard deviation of monthly mean values.
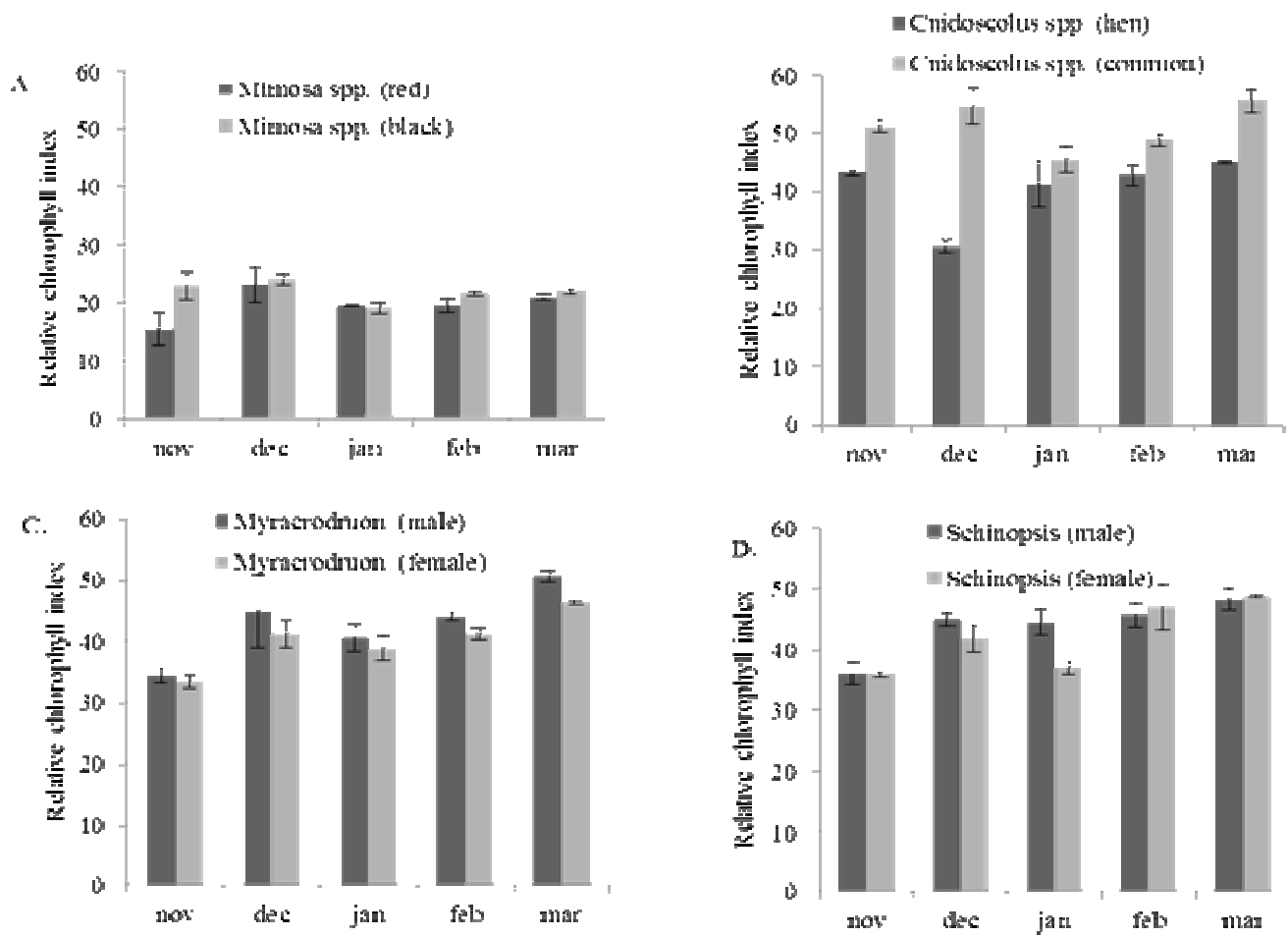

Figure 3. Chlorophyll content of Mimosa spp. (A), Cnidoscolus spp. (B), Myracrodruon urundeuva M. Allem. (C), and Schinopsis brasiliensis Engl. (D) during the experiment period, from November to March. The bars in each column indicate the standard deviation of mean values.

According to Suresh et al. (2012), oil palm trees show no effects of drought stress on photochemical machinery, partly due to the maintenance of high photosynthetic pigment contents and efficient photoprotection mechanisms.

Net photosynthesis suffered many fluctuations during the experiment period in all species (Figure 4). The lowest rates were found in
C. quercifolius and C. bahianus during most of the experiment period (Figure 4C). These reduced rates were similar to Jatropha curcas (a species of the Euphorbiaceae family, well adapted to Caatinga), in which photosynthetic rates are lower than $5 \mu \mathrm{mol}$ $\mathrm{m}^{-2} \mathrm{~s}^{-1}$ in the semi-arid region (SANTOS et al., 2013). 

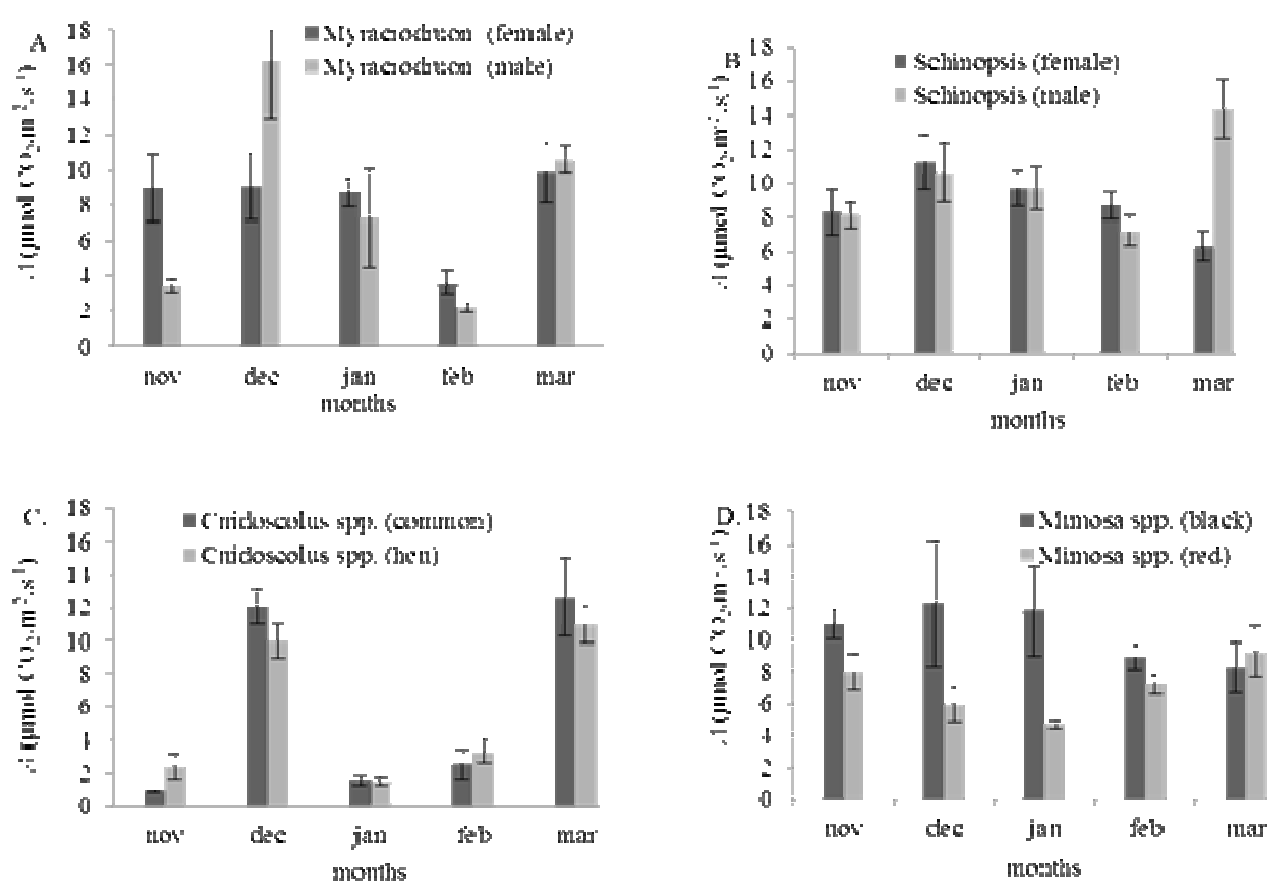

Figure 4. Net photosynthesis (A) in Myracrodruon urundeuva M. Allem. (A), Schinopsis brasiliensis Engl. (B), Cnidoscolus spp. (C), and Mimosa spp. (D) during the experiment period, from November to March. The bars in each column indicate the standard deviation of mean values.

Regarding photosynthetic rates among species, there was a significant difference only in Mimosa spp. Photosynthetic rates of M. tenuiflora were higher than that of $M$. arenosa (Figure 4D). In Cnidoscolus spp., there was no difference between Cnidoscolus quercifolius Pohl. and C. bahianus (Figure 4C). Photosynthetic rates of S. brasiliensis, both in male and female plants, were similar almost throughout the experiment period, except for May, when net photosynthesis in "males" was higher than in "females" (Figure 4B).

According to Oliveira et al. (2016), the mean $P N$ of $S$. coronata during rainy and dry periods was 10 and $2 \mu \mathrm{mol} \cdot \mathrm{m}^{-2} \cdot \mathrm{s}^{-1}$, respectively, which also occurred in native species of the Caatinga as shown in Fig. 2 A and B. This same author reports that net photosynthesis rate differed between seasons but not between diurnal periods.

Decreases in transpiration, stomatal conductance, and net photosynthesis have been observed in Myracrodruon urundeuva M. Allem. under water deficit (Mariano et al., 2009). Furthermore, these authors have detected different physiological responses according to leaf location in the canopy: basal $\left(3,17 \mu \mathrm{mol} \mathrm{m} \mathrm{m}^{-2} \mathrm{~s}^{-1}\right)$, intermediate $\left(6,91 \mu \mathrm{mol} \mathrm{m} \mathrm{m}^{-2} \mathrm{~s}^{-1}\right)$, and top $\left(2,74 \mu \mathrm{mol} \mathrm{m} \mathrm{m}^{-2} \mathrm{~s}^{-1}\right)$. Photosynthesis rates of Myracrodruon urundeuva M. Allem. plants in the present study (Figure 4A) were slightly higher than those reported by Mariano et al. (2009), and Souza et al. (2016), except for the month of February, when they were measured in an intermediate location in the canopy.

All species evaluated had lower transpiration and stomatal conductance in January and February (Figures 5 and 6), and this may be a plant response to the decreased precipitation in those months. When environmental conditions are normal, leaf transpiration is mainly regulated by sun radiation, vapor pressure deficit, and stomatal conductance. However, in plants under stress, transpiration decrease is a consequence of stomatal closure, which is a usual leaf response to water deficit.

The effect of stomatal closure on transpiration decrease was more evident in "aroeira" and "favela" species, as reported previously (Figures 6 A,C and 5 A,C). This behavior is similar to "pinhão manso" (Jatropha curcas) in the same semiarid environmental conditions (SANTOS et al., 2013). Transpiration rates of "baraúna" (S. brasiliensis Engl.) varied from 2.4 to $3.2 \mathrm{mmol} \mathrm{m}^{-2}$ $\mathrm{s}^{-1}$, and their behavior is similar to that previously reported by Silva et al. (2010 and 2013), but higher than the values observed by Oliveira et al. (2016). According to these authors, transpiration decrease is due more to low soil water availability than to stomatal control. However, stomatal closure has been considered the main cause of transpiration decrease in "pinhão manso" (Jatropha curcas) (SILVA et al., 2013). 

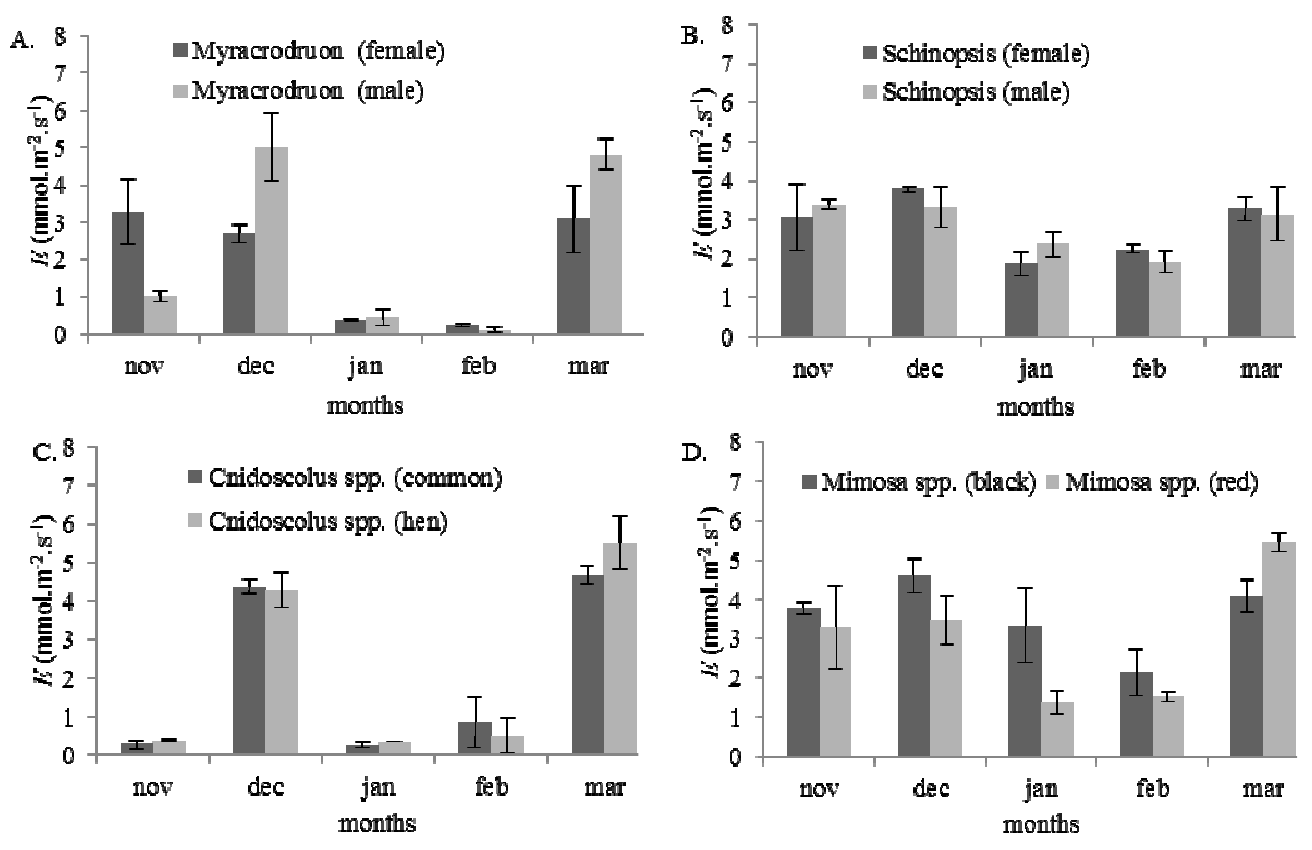

Figure 5. Transpiration rates (E) in Myracrodruon urundeuva M. Allem. (A), Schinopsis brasiliensis Engl. (B), Cnidoscolus spp. (C), and Mimosa spp. (D) during the experiment period, from November to March. The bars in each column indicate the standard deviation of mean.
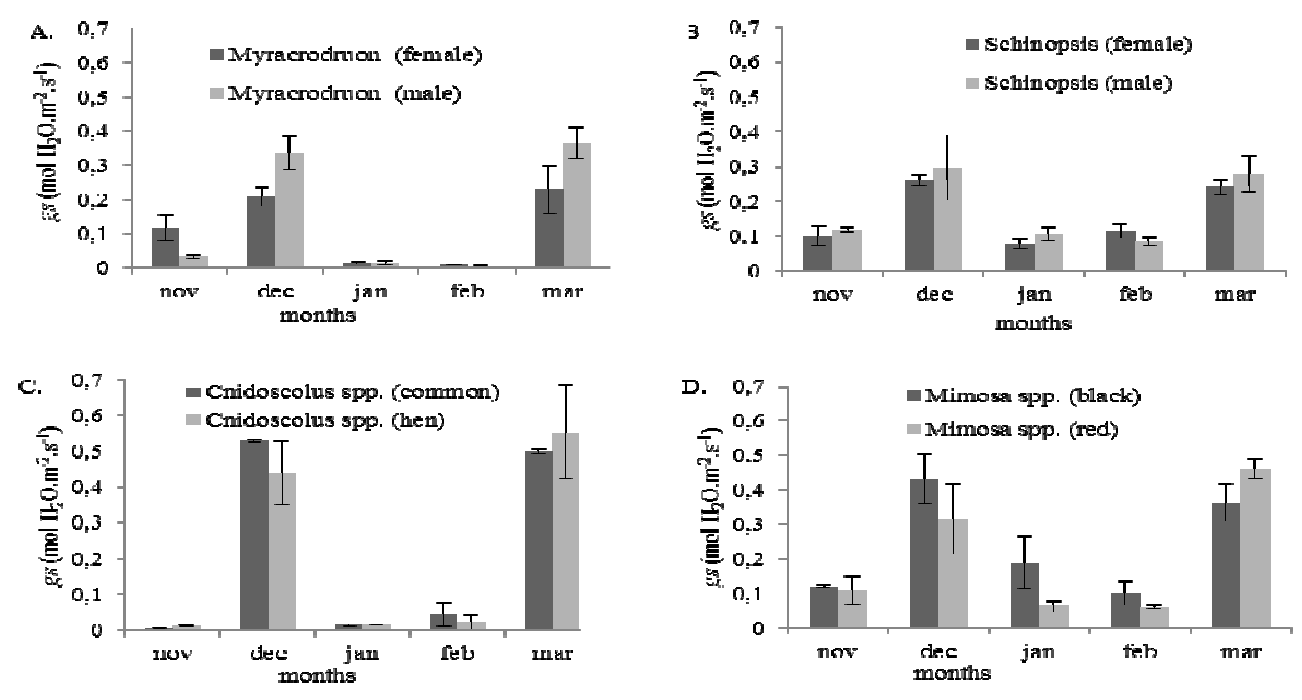

Figure 6. Stomatal conductance ( $g s$ ) in Myracrodruon urundeuva M. Allem. (A), Schinopsis brasiliensis Engl. (B), Cnidoscolus spp. (C), and Mimosa spp. (D) during the experiment period, from November to March. The bars in each column indicate the standard deviation of mean.

The majority of Caatinga species has developed morphological and physiological adaptations to survive during drought periods, e.g. stomatal closure, leaf area reduction by leaf drop, and osmotic adjustment. This phenomenon causes an immediate increase in WUE, as observed in oil palm (SURESH et al. 2012).
Stomatal closure reduces both gas and water exchanges between leaf and air, leading to a lower internal $\mathrm{CO}_{2}$ concentration (OLIVEIRA et al., 2016). Thus, $\mathrm{CO}_{2}$ diffusion from stomata to chloroplasts becomes lower, reducing photochemical efficiency and net assimilation rate (SANTOS et al., 2006; RIBEIRO et al. 2008). The same trends of reduced gs and PN during periods of 
low water availability have also been observed in other palm species (OLIVEIRA et al.2002; OLIVEIRA et al. 2016), in which the reduction of gs leads to a higher decrease in $\mathrm{E}$ than in PN.

\section{CONCLUSIONS}

The studied species have different performances under water deficit in the Caatinga environment.

In all species, both transpiration and stomatal conductance decreased when precipitation became scarce. This decrease only led to a significantly decreased photosynthesis rate in "aroeira" and "favela", which have shown to be more sensitive to drought effects.
"Baraúna" and "jurema" seem to be more tolerant species, due to their slight decrease in photosynthesis as a response both to low stomatal conductance and to water availability.

\section{ACKNOWLEDGMENTS}

The authors would like to thank to Dr. Lúcia Helena Piedade Kiill for all of her precious insights; and to the Foundation for Research Support of Pernambuco (FACEPE) and the National Council of Scientific and Technological Development (CNPq) for their financial support and regional scientific development scholarship (DCR).

RESUMO: A Caatinga é um bioma do semiárido brasileiro que precisa ser mais estudado, para preservar suas espécies nativas. O objetivo deste estudo foi avaliar o comportamento fisiológico de seis espécies nativas. O experimento foi organizado em seis tratamentos (espécies nativas) e três repetições em um delineamento de blocos ao acaso. Foram avaliadas a fotossíntese líquida, transpiração, condutância estomática, densidade DE fluxo de fótons fotossintéticos, teor de clorofila e umidade do solo. De acordo com os resultados, Mimosa spp., mostrou os níveis mais baixos de teor de clorofila. Em todas as espécies, o déficit hídrico provoca diminuição significativa na taxa de transpiração e na condutância estomática. M. urundeuva e Cnidoscolus spp., podem ser consideradas as espécies mais sensíveis à seca, porque as mudanças nessas variáveis levaram também ao declínio da fotossíntese líquida. As outras espécies podem ser consideradas mais tolerantes à seca, pois, apesar dos efeitos nocivos do déficit de água na transpiração e na condutância estomática, a fotossíntese líquida não sofre queda significativa.

PALAVRAS-CHAVE: Fotossíntese. Relação planta-água. Seca. Semiárido brasileiro.

\section{REFERENCES}

ARAÚJO, E. L, CASTRO, C. C., ALBUQUERQUE, U. P. Dynamics of Brazilian Caatinga - A review concerning the plants, environment and people. Functional Ecosystems and Communities, v. 1, p. 15-28, 2007.

DONOHUE, R. J., RODERICK, M. L., MCVICAR, T. R., FARQUHAR, G. D. $\mathrm{CO}_{2}$ fertilization has increased maixumum foliage cover across the globe's warm, arid environments. Geophysical Research Letters, v. 40, p. 3031-3035, 2013. https://doi:10.1002/grl.50563

FENG, Y. L., CAO, K. F. Photosynthesis and photoinhibition after night chilling in seedlings of two tropical tree species grown under three irradiances. Photosynthetica, v. 43, p. 567-574, 2005.

FERREIRA, D. F. Sisvar: a computer statistical analysis system. Ciência e Agrotecnologia, v. 35, p. 10391042, 2011. http://dx.doi.org/10.1590/S1413-70542011000600001

GALVÍNCIO, J. D., PIMENTEL, R. M. M., FERNANDES, J. G. Relação da temperatura do ar e do solo com a quantidade de clorofila a e b em jurema preta (Mimosa tenuiflora (Willd) Poiret) no semi-árido do Nordeste do Brasil. Revista Brasileira de Geografia Física,v. 3, p. 41-46, 2010.

GIULIETTI, A. M., QUEIROZ, L. P. Recursos genéticos do semi-árido, v. 5, p. 73-110, 2006. Recife: Instituto do Milênio do Semi-árido. 
GUO, X. Y., ZHANGL, X. S., HUANG, Z. Y. Drought tolerance in three hybrid poplar clones submitted to different watering regimes. Journal of Plant Ecology, v. 3, p. 79-87, 2010. https://doi.org/10.1093/jpe/rtq007

HESSini, K., MARTINEZ, J. P., GANDOUR, M., ABBOUCHI, A., SOLTANI, A., ABDELLY, C. Effect of water stress on growth, osmotic adjustment, cell wall elasticity and water-use efficiency in Spartina alterniflora. Environmental and Experimental Botany, v. 67, p. 312-319, 2009.

https://doi.org/10.1016/j.envexpbot.2009.06.010

IBGE - Instituto Brasileiro de Geografia e Estatística. Levantamento sistemático da produção agrícola. Rio de Janeiro: IBGE, 2010.

JOHARI-PIREIVATLOU, M., QASIMOV, N., MARALIAN, H. Effect of soil water stress on yield and proline content of four wheat lines. African Journal of Biotechnology, v. 9, p. 36-40, 2010. https://doi: 10.5897/AJB09.521

MARIANO, K. R., BARRETO, L. S., SIlVA, A. H. B., NEIVA, G. K. P., AMORIM, S. Fotossíntese e tolerância protoplasmática foliar em Myracrodruon urundeuva Fr. All. submetida ao déficit hídrico. Revista Caatinga, v. 22, p. 72-77, 2009. http://dx.doi.org/10.5380/rf.v39i4.16320

MOURA, N. A., ARAÚJO, E. L., ALBUQUERQUE, U. P. Biodiversidade, potencial econômico e processos ecofisiológicos em ecossistemas nordestinos. Recife: Editora Comunigraf, 2008.

OLIVEIRA, D., MEDEIROS, M., PEREIRA, S., OLIVEIRA, M., FROSI, G., ARRUDA, E., SANTOS, M. Ecophysiological leaf traits of native and exotic palm tree species under semi-arid conditions. Bragantia, v. 75, p.128-134, 2016. http://dx.doi.org/10.1590/1678-4499.364

RIBEIRO, R. V., SANTOS, M. G, MACHADO, E. C., OLIVEIRA, R. F. Photochemical heat-shock response in common bean leaves as affected by previous water deficit. Russian Journal of Plant Physiology, v. 55, p. 350-358, 2008. https://doi: 10.1134/S1021443708030102

SANTOS, C. M., VERISSIMO, V., LINS, H. C., FILHO, W., FERREIRA, V. M., CAVALCANTE, P. G. S. Seasonal variations of photosynthesis, gas exchange, quantum efficiency of photosystem II and biochemical responses of Jatropha curcas L. grown in semi-humid and semi-arid areas subject to water stress. Industrial Crops and Products, v. 41, p. 203-213, 2013. https://doi.org/10.1016/j.indcrop.2012.04.003

SANTOS, M. G., RIBEIRO, R. V., OLIVEIRA, R. F., MACHADO, E. C., PIMENTEL, C. The role of inorganic phosphate on photosynthesis recovery of common bean after a mild water deficit. Plant Science, v. 170, p. 659-664, 2006. https://doi.org/10.1016/j.plantsci.2005.10.020

SILVA, E. N., FERREIRA-SILVA, S. L., FONTENELE, A. V., RIBEIRO, R. V., VIÉGAS, R. A.,SILVEIRA, J. A. G. Photosynthetic changes and protective mechanisms against oxidative damage subjected to isolated and combined drought and heat stresses in Jatropha curcas plants. Journal of Plant Physiology, v. 167, p. 11571164, 2010. https://doi: 10.1016/j.jplph.2010.03.005

SILVA, E. N., VIEIRA, S. A., RIBEIRO, R. V., PONTE, L. F. A., FERREIRA-SILVA, S. L., SILVEIRA, J. A. G. Contrasting physiological responses of Jatropha curcas plants to single and combined stresses of salinity and heat. Journal of Plant Growth Regulation , v. 32, p. 159-169, 2013. https://doi: 10.1007/s00344-0129287-3

SURESH, K., NAGAMANI, C., KANTHA, D. L., KUMAR, M. K. Changes in photosynthetic activity in five common hybrids of oil palm (Elaeis guineensis Jacq.) seedlings under water deficit. Photosynthetica, v. 50, p. 549-556, 2012. http://dx.doi.org/10.1007/s11099-012-0062-2. 
TROVÃO, D. M. B. M., FERNANDES, P. D., ANDRADE, L. A., NETO, J. D., OLIVEIRA, A. B., QUEIROZ, J. A. Avaliação do potencial hídrico de espécies da Caatinga sob diferentes níveis de umidade do solo. Revista de Biologia e Ciências da Terra, v. 11, p. 307-311, 2007.

YU, D. J., KIM, S. J., LEE, H. J. Stomatal and non-stomatal limitations to photosynthesis in field-grown grapevine cultivars. Biologia Plantarum, v. 53, p. 133-137, 2009. https://doi: 10.1071/PP99019_CO

ZHENG, Y. L., FENG, Y. L., LEI, Y. L., YANG, C. Y. Different photosynthetic responses to night chilling among twelve populations of Jatropha curcas. Photosynthetica, v. 47, p. 559-566, 2009.

https://doi: 10.1007/s11099-009-0081-9 